\title{
酵母による豆乳の凝固について
}

\author{
橋 本 俊 郎*・木村宏忠*・高 橋 清*
}

\section{Coagulation of Soybean Milk by Culture of Yeast}

\author{
Toshiro Hashimoto, Hirotada Kimura and Kiyoshı TaKahashi* \\ * Ibaraki Food Research Institute, Nagaoka 3781, Ibaraki-machi, \\ Ibaraki-ken, 311-31
}

\begin{abstract}
The use of Saccharomyces cerevisiae (for sake, wine and bread etc.) for the manufacture of soybean protein curd from soybean milk was investigated. $S$. sake coagulated soybean milk easily by culture on $30^{\circ} \mathrm{C}$, but under the same conditions, it did not coagulate milk and skim added $2 \%$ glucose. The compositions of soybean curds which were obtained by use of sake, wine bread yeasts were similar to tofu, but those curds had fermented flavour instead of beany flavour. Protein and fat yields in curds were approximately $86 \sim 88 \%$ and $100 \%$, respectively. During the process of fermentation, $S$. sake formed acetic acid, succinic acid and malic acid, and it was suggested that coagulation was caused by acidic products. In case of $S$. rouxii, coagulation of soybean milk was slower than that with $S$. cerevisiae.

(Received Aug. 6, 1984)
\end{abstract}

丸太豆から熱水抽出して得られる豆乳を利用して, 新 しい大豆蛋白食品素材の開発を試みた。

豆腐製造では, 豆乳の凝固のために, 無機塩類 ( $\mathrm{Ca}$ 塩, $\mathrm{Mg}$ 塩)，あるいはグルコノデルタラクトンが用いられ る。豆乳利用チーズ状食品製造においては，カード形成 のために，乳酸菌の乳酸発酵を利用することが多く，醉 母を併用する場合は, 蛋白分解力の強い酵母を用いて, 熟成を目的とている(12)と考えられる。著者らは，一般 的な乳酸菌を豆乳カード化に用いた場合, 豆乳特有の臭 いがとれず，をた，酸度の調節が困難であったことに比 し，清酒醉母やパン酵母単独の作用により豆乳の㠜固が 容易に起こり，豆乳臭をほとんど感じさせない大豆蛋白 の凝固物が得られることを見い出したので，分析的方法 により検討した。

\section{実 験 方 法}

\section{1. 豆乳}

茨城県産大豆（エンレイ，タマホマレ）を用い, 最終 加水量 8 10 倍の豆乳を得た。すなわち，磨砕したご汁

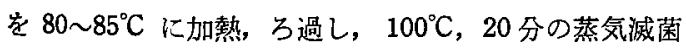
を行った。必要に応し，食添用グルコースを $0.5 \sim 10 \%$
の範囲で添加・補糖した。

\section{2. 使用酵母}

清酒酵母（醕造協会 10 号）を主に用い，他にワイン 醭母（協会ブドウ 2 号)，パン酵母（市販品）ならびに 味そ酵母（Saccharomyces rouxii）を，いずれ屯婑汁液 体培地に前培養して用いた。

\section{3. 乳豆の凝固試験方法}

一定量の豆乳を三角フラスコに入れ，前培養した酵母 を $1 \mathrm{ml}$ 加之, $30^{\circ} \mathrm{C}$ で一定時間静置培養した。

酵母に上る凝固は，副生する炭酸ガスのため，小孔の 多い㠜固物となり，発酵の進行と共に大部分が液体部 （ホェー）の上に浮上する。そこで，凝固物（カード）之 ホェーの分離には，バスケット型遠心分離（サランろ布 使用， $3000 \mathrm{rpm}, 5$ 分）あるいは遠沈管を使用した遠 心分離 (3000 rpm, 10 分) によって，その後の測定に 供した。

\section{4. 分析法}

(1) 一般成分

$\mathrm{pH}$ ，水分 (固形分) は常法による。総案素はケルダー ル分解法。還元煻はソモギー変法, 粗脂肪はソックスレ ーエーテル抽出法。灰分は $600^{\circ} \mathrm{C}$ 乾式灰化法。全りンは

*茨城県食品試験所（广 311-31 茨城県東茨城郡茨城町長岡 3781） 
メタバナジン酸法。

(2) アルコール

GLC による。充てん削 Porapack Q を用いた絶対検 量線法。

(3) 有機酸

東京理化器機械製カルボン酸分析計使用。

(4) 酵母数の計測

トーマの血球計測器使用, もしくは麴汗寒天培地によ る平板培養法。

(5) 無機成分 $(\mathrm{K}, \mathrm{Ca}, \mathrm{Mg})$

原子吸光光度計を使用し, 炎光法もしくは原子吸光法。

\section{実 験 結 果}

\section{1. 清酒酵母による豆乳と牛乳の凝固試験}

牛乳や眖脂乳を原料とし，チーズ様食品 ${ }^{81}$ や乳酒4を 製造する研究がなされている。そこで市販牛乳, $10 \%$ 脱 䁕乳拉よび豆乳（固形分 $7.0 \%$ ）を培地とし，さらにそ れらの培地にグルコースを $2 \%$ となるよう補糖し, 清酒 酵母を $4.6 \times 10^{6}$ 個 $/ \mathrm{g}$ となるように接種し， $30^{\circ} \mathrm{C}$ で 40 時間の静置培養した。

その結果, 豆乳を培地としたもののみに，凝固が起こ り，特に $2 \%$ 補糖豆乳は，遠心分離によってほとえど透 明なホェーと白色のカードが得られた。醉母接種前の豆 乳の $\mathrm{pH}$ は 6.78 であったが，凝固時のそれは 5.96〜 6.00 と低下し，酵母数は $10^{8}$ 台に増加した。一方， $2 \%$ のグルコースを添加した牛乳，脱脂乳の $\mathrm{pH}$ は $5.95 \sim$ 6.08 と低下し，酵母数も $10^{8}$ 台に増加していたが，凝 固した様子は認められなかった。

\section{2. 数種の酵母による豆乳の凝固試験}

ほじめに豆乳への補糖量の決定のため,グルコース添 加量を 2,5 および $10 \%$ と変えて, 清酒醉母安接種し, 24 時間培養して分離した。

グルコース無添加区は，ホエーがやや白濁し，水分の 多いカードとなり，2\% 以上の補糖区で，透明なホェー としっかりしたカードが得られた。しかし，5\%以上の 補糖区のカードは残糖が多く，分離後にも発酵が続いた。

そこで，補糖量は $2 \%$ とし，2\%グルコース添加豆乳 $700 \mathrm{~g}$ に対し清酒酵母, ワイン酵母, パン酵母および味

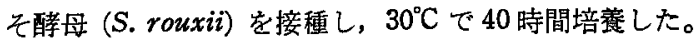
LODDER の分類によるS. cerevisiae に属する 3 種の酥 母添加区にカード化が起きたが，S. rouxii 添加区は凝 固しなかった。味そ酵母添加区の 40 時間培養後の $\mathrm{pH}$ は，6.60 と，他の䤉母添加区のそれ（pH 5.6〜6.0）と 比ベて低下しなかったが，さらに長期間の培養によって
表 1 醳母による豆乳カードの性状

\begin{tabular}{|c|c|c|c|}
\hline & 清酒酵母 & パン酳母 & ワイン醏母 \\
\hline 収量（g） & 306.0 & 299.2 & 314.4 \\
\hline 固形分（\%） & 12.24 & 12.67 & 12.07 \\
\hline $\mathrm{pH}$ & 5.97 & 5.98 & 5.95 \\
\hline 総窒素（\%） & 1.25 & 1.27 & 1.19 \\
\hline 粗たえ白（\%） & 7.13 & 7.23 & 6.20 \\
\hline 粗脂肪（\%) & 3.20 & 3.28 & 3.13 \\
\hline 全糖（\%) & 0.42 & 0.41 & 0.38 \\
\hline 粗扊分（\%） & 0.45 & 0.47 & 0.42 \\
\hline 全リン (mg\%) & 76.0 & 86.0 & 83.0 \\
\hline
\end{tabular}

豆乳（固形分 $7.01 \%$ ，総窒素 $0.617 \%, \mathrm{pH} 6.78$ ) 700 gにグルコースを $2 \%$ 添加し, 各醉母を接種後 $30^{\circ} \mathrm{C}$, 40 時間培養。バスケット型遠心分離機で分離し,カード とする。

凝固した。この凝固物は，醬油様のフレーバー有して いた。S. cerevisiae 添加によって得られるカードは, 酒 粕あるいはワイン風のフレーバーを有し，それらのカー ドの性状を表 1 に示した。

豆乳からの窒素成分の回収率は，87〜89\%であり， 豆腐製造における移行率和，川口ら での回収率などと同様であった。粗脂肪の回収率は，い

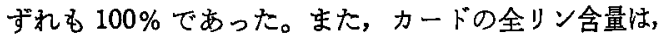
カード蛋白質の $1.1 \sim 1.2 \%$ であり，酸沈蛋白に類似し ている゙。三種の酵母によるカードの成分は，ほとんど 変わらず, フレーバーがやや異なるが，凝固の機構は本 質的に変らないるのと考えられる。

\section{3. 低濃度補糖，培養日数と凝固との関係}

醉母によるカード化のために添加するグルコース量 は，実用上少ない方がよいと考光，補糖量它 $0,0.5,1$ および $2 \%$ とし，培養日数を $1 ， 2 ， 3$ 日間とし，清酒 酵母を使用してカード化した。

遠心分離前の発醉物について，pH および酵母数を計 測し，分離後のホェーについて，アルコール，有機酸和 よび窒素成分を定量し，カードについて水分含量と豆孚 臭の有無調べた。清酒醉母の添加量は, $2.7 \times 10^{6}$ 個 $/ \mathrm{g}$ であった。

1 日および 3 日間培養後の結果を, 表 2 , 表 3 に示し た。豆乳のアルコールは 0\%であったが, 補糖量に比例 して增加し， $2 \%$ 補糖で $1.2 \%$ 台となった。ホエーの窒 素成分から，凝固した蛋白質は補糖量が多い程增加し， 補䌅量 2\%，1日培蕞で蛋白質の取率はおよそ $85 \%$ と なりその後の培䪷によっても变化しなかった。カード 
表 2 補糖量の違いによる豆乳発酵物の性状（1 日培養）

\begin{tabular}{|c|c|c|c|c|c|}
\hline & \multirow{2}{*}{ （原料豆乳） } & \multicolumn{4}{|c|}{ グルコース添加量 } \\
\hline & & 無補糖 & $0.5 \%$ & $1.0 \%$ & $2.0 \%$ \\
\hline pH & 6.78 & 5.92 & 5.82 & 5.74 & 5.66 \\
\hline フルコール（\%) & 0.0 & 0.335 & 0.536 & 0.732 & 1. 021 \\
\hline ホエーの総窒素（\%） & 0.588 & 0.111 & 0.103 & 0.094 & 0.091 \\
\hline 酰酸（mg\%） & 3.5 & 10.1 & 13.7 & 14.8 & 18.8 \\
\hline クェン酸（mg\%） & 177.1 & 187.6 & 188.6 & 186.6 & 185.5 \\
\hline コハク酸（mg\%） & 5.0 & 8.4 & 13.5 & 16.9 & 21.9 \\
\hline 醳母数 $\left(\times 10^{7} / \mathrm{m} l\right)$ & - & 3.9 & 4.3 & 4.4 & 4.2 \\
\hline カードの水分 $(\%)$ & 93.0 & 91.3 & 90.6 & 89.4 & 87.9 \\
\hline 豆釈臭 & ++ & ++ & + & + & +- \\
\hline
\end{tabular}

清酒酵母 $2.7 \times 10^{6}$ 接種

表 3 補糖量の遠いによる豆釈発醉物の性状 ( 3 日培養)

\begin{tabular}{|c|c|c|c|c|}
\hline & \multicolumn{4}{|c|}{ グルコース添加量 } \\
\hline & 無補糖 & $0.5 \%$ & $1.0 \%$ & $2.0 \%$ \\
\hline $\mathrm{pH}$ & 5.95 & 5.85 & 5.79 & 5.64 \\
\hline アルコール（\%) & 0.297 & 0.516 & 0.799 & 1.230 \\
\hline ホエーの䌋窒素（\%) & 0.113 & 0.108 & 0.099 & 0.093 \\
\hline 酢酸（mg\%） & 18.3 & 24.3 & 22.9 & 28.6 \\
\hline クェン酸（mg\%） & 200.0 & 198.3 & 197.9 & 191.7 \\
\hline コハク酸（mg\%） & 10.4 & 15.7 & 18.4 & 27.0 \\
\hline 醉母数 $\left(\times 10^{7}\right)$ & 4.6 & 5.2 & 6.1 & 5.8 \\
\hline カードの水分 $(\%)$ & 91.4 & 90.0 & 89.8 & 87.8 \\
\hline 豆乳臭 & + & - & - & - \\
\hline
\end{tabular}

の含水量が 1 日培養以降，ほとえど一定であることから， 睹母にる豆乳の㠜固は 24 時間で完了したと思われる。 接種醭母数 (初発菌数) と凝固に要する時間との関係は, 初発菌数が多い程, 速かに凝固が起こり, 凝固時の酵母 数は少なくとも $10^{7}$ 台に達していることが必要であり， 今回の試験ではいずれの区す 1 日培盖で $10^{7}$ 台に達し, その後の増加はわずかであった。

前に, S. rouxii 添加でも長期の培養で㠜固が起こる


/g (3 日間培養) であり，凝固が於そいのは，同酵母の 豆乳中での増殖速度が低いためと考えられる。

豆乳の有機酸組成は，クェン酸が $93 \%$ を占め, 大豆 の有機酸組成とほほ一致している。酵母添加, 培養によ り, ホェー中に㼍酸，コハク酸，リンゴ酸が増加し， 2 \% 補糖，1日培酵区でこれらの酸は $24 \%$ 増となった。

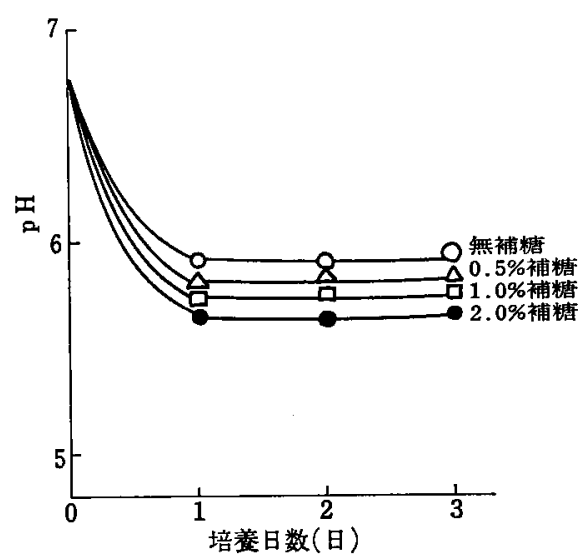

図 1 清酒醳母による豆釈凝固における $\mathrm{pH}$ の変化

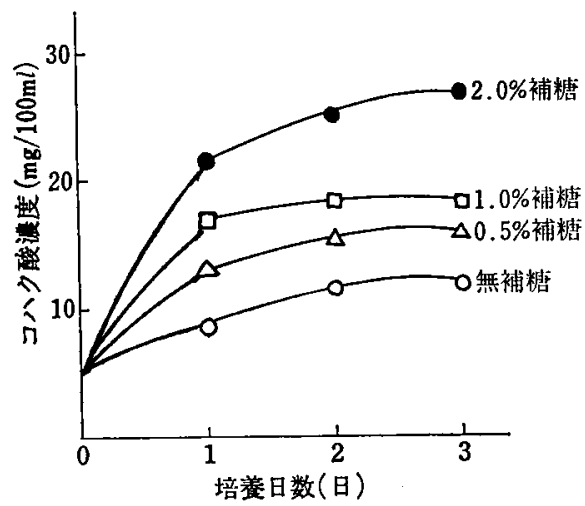

因 2 清酒酵母による豆乳凝固における コハク酸の変化 
醉母のフルコール発醳において，同時に少量の有銭酸を 生成することはよく知られたこと8)であり，豆乳中での 有機酸生成が $\mathrm{pH}$ 低下の要因となっているるのと思われ る(四 1, 図 2)。

原料とした豆加の豆乳臭は好ましいものでない。この 豆乳臭は，GLC 分析によれば，一キサナール，一キサ， ールを主成分とするすのではなかった。官能的に，醉母 添加による豆乳真の消失は，1 日培養では不足であり， 2 日以上の培養によって好ましい発醳臭におきかわっ た。

\section{4. 豆乳の凝固における酵母の役割}

酵母の増殖によって豆乳が凝固する理由を検討した。 グロブリンは水不溶性であるが，希薄塩類溶液に溶解 (塩溶効果) する。グロブリンに属する大豆蛋白質は, 豆乳として抽出され，これは大豆に含まれる塩類による ものといわれている。また, 脱脂大豆より食塩溶液で抽 出された大豆グロプリンは，透析によって水不溶性とな る゙。一方, 醉母の増殖にはカリウムやリンなどの無機 成分を要求し, 増殖によって塩濃度が低下する可能性が ある。醉母による豆乳の㠜固後，ホェーとカードに分離 し，K， Ca，Mg および P の分布を調べた（表 4)。 その結果, $\mathrm{K}, \mathrm{Mg}$ および Ca はカードとホェーに, ほほ一様に分布し, カード中の $\mathrm{K}$ と $\mathrm{Mg}$ は, 水洗浄に よって大部分が溶出した。大豆に含まれる全リンの 70 〜 80\% はフィチン態で存在し, $\mathrm{Ca}$ 塩あるいは酸沈潅の 際にに共沈するといわれている9が，醉母凝固でも他の 無機成分とは異なり，カードへの分布が大であり，蛋白 質と共沈していた。したがって，醉母凝固における塩浱 度の影響はないものと思われる。

醉母による大豆蛋白カードは，pH 11 でほとんど溶解

表 4 豆拜の凝固における無機成分の分布

\begin{tabular}{|c|c|c|c|}
\hline & 原料豆乳 & ホェー & カート \\
\hline 重量（収量）（g） & 100.0 & 73.5 & 26.5 \\
\hline 絵窒素 (\%) & 0.473 & $\begin{array}{l}0.028 \\
(6.0)^{*}\end{array}$ & $\begin{array}{c}0.438 \\
(92.6)\end{array}$ \\
\hline カリウム (ppm) & 1412 & $\begin{array}{r}1400 \\
(72.9)\end{array}$ & $\begin{array}{r}1617 \\
(30.3)\end{array}$ \\
\hline カルシウム (ppm) & 96 & $\begin{array}{r}90 \\
(68.9)\end{array}$ & $\begin{array}{r}101 \\
(30.0)\end{array}$ \\
\hline マグネシウム（ppm) & 181.0 & $\begin{array}{l}178.3 \\
(72.4)\end{array}$ & $\begin{array}{r}194.4 \\
(28.5)\end{array}$ \\
\hline リ ン (ppm) & 507.6 & $\begin{array}{r}347.8 \\
(50.4)\end{array}$ & $\begin{array}{l}922.8 \\
(48.2)\end{array}$ \\
\hline
\end{tabular}

し， $\mathrm{pH} 12$ で完全に溶解した。酸性側では完全な溶解は みられなかった。豆乳に Ca 塩や GDLを作用させた場 合の凝固について，橋詰ら ${ }^{10}$ は，酸凝固である GDL ケ゚ ルは水素結合, 疎水結合, S-S 結合が重要な役割を果し

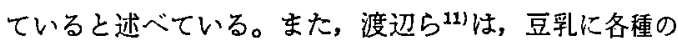
酸類および塩類を作用させて，酢酸やリンコ酸などの有 機酸を用いた場合，上澄の $\mathrm{pH} か ゙ 6.0$ 付近のときに，ほ ほ完全に凝固することを報告している。

以上のことから，酥母による豆乳の㠜固は，殺菌など により熱変性された大豆蛋白質の発醅時に副生する有機 酸による酸㠜固であるうと推定した。

なお，発䤃で生ずる炭酸ガスとフルコールの㠜固への 影餂について，次の上うな試験を行った。すなわち，炭 酸ガス発生装置よりガラス管で豆乳中に炭酸ガスを導入 し，凝固するか否かをみた。通気 18 時間で $\mathrm{pH}$ は 5.9 前後に低下しペースト状となったが，カードとしての 分離は困難であった。更にェチルアルコールを $1 \%$ にな るように添加して 48 時間通気したが，カード化にいた らなかった。

要約

大豆から熱水抽出して得られる豆乳に，清酒䤃母，口 イン酵母およびパン䤉母を作用させ，豆乳真のない大豆 蛋白カードを製造した。

（1）清酒醰母を接種し培養させることによう，2\%グ ルコースを補糖した牛乳，脱脂乳は㠜固しなかったが， 同条件で，豆乳は凝固，カード化した。

（2）清酒醉母，ワイン醉母およびパン醉母によって， 豆乳から得られたカードは，いずれも蛋白質の凝固率 $86 \sim 88 \%$ ，粗脂肪の㠜固率 $100 \%$ と，他の豆乳関連食品 （豆腐など）に類似していたが，淡白な味と不快でない 発醉臭を有していた。

(3) 豆乳に接揰した清酒醉母は，フルコールと共に酶 酸、コハク酸,リンゴ酸を生成しこれらの有機酸が豆 乳蛋白質の凝固に主要な役割を果していると推定した。

終りに臨み，有益な御助言を睗わりました食品総合研 究所の斎尾氏，伊藤氏に深謝いたします。

$$
\text { 文献 }
$$

1）松岡博厚 - 笹子謙治 - 関口正勝：日食工誌，15, 103 (1968).

2) 川口 豊: 日食工誌, 27, 1 (1980).

3）津郷友吉・張 堅二: 日音会報, 41, 445 (1970).

4) 越智猛夫: 東北福祉大学紀要, 創刊号 (1974). 
5）中山悠・深町千晴・久保彰治 - 駿河幸子・宮永 節子・堀家静子・渡辺篤二：食総研報，14 B, 53 (1960).

6) 川口 豊・松風博厚：日食工誌，28，8 (1981).

7) 渡辺䉆二・海老根英雄 -太田輝夫：大豆食品， 2 版 (光琳), p. 12 (1980).
8）清酒酵母研究会：改訂清酒酵母の研究， p. 326 (1980)

9）斎尾基子 - 渡辺篤二：油脂，21，10, 115 (1968).

10）橋詰和宗・何 銀蘭：日食工誌, 25, 383 (1978).

11）渡辺篤二. 阿部和可：日食工誌, 9, 158 (1962). (昭和 59 年 8 月 6 日受理)

\section{新刊紹介 \\ 食品分析一原理と方法一第 2 卷, 物理化学的方法 \\ Dieter, W., GRUenWEdel and \\ JOHN R. WHITAKER 編}

8 巻シリーズの第 2 巻。食品の品質に関連する物理的 特性，原子から分子までの分析における物理化学的な方 法を，最近の進歩をふまえて記述している。以下の 12 章で構成されている。温度測定。溶解性。粘度。光学顕 微镜。柴外・可視分光。生物分子の光学活性と構造。蝵 光とリン光。電子スピン共鳴法。原子吸光法。食品技術 における赫分光法。食品のキャラクタリセ゚ーションの ラマン分光法の応用。低角度レーザー光散乱を検出器と する Size exclusion chromatographyによる分子量測 定。本文と図表, 交献, 索引を含め 591 ページ, 107.5 ドル

Marcel Dekker Inc., 270 Madison Avenue,

New York, N. Y. 10016, U.S. A. 